\title{
MANAJEMEN KINERJA
}

\author{
Oleh: Nasrullah Nursam \\ Alumnus Prodi Manajemen, Universitas Muslim Indonesia Makassar \\ E-Mail : nasrullahnursam778@yahoo.com
}

\begin{abstract}
Abstrak
Manajemen kinerja tradisional mempunyai kelemahan-kelemahan dan tidak sesuai lagi diterapkan oleh organisasi bisnis dalam memasuki persaingan yang sangat ketat di pasar global. Manajemen kinerja tradisional harus ditinggalkan dan diganti dengan menerapkan manajemen kinerja baru. Perbaikan manajemen kinerja dilakukan secara berkelanjutan untuk mengantar kinerja karyawan, tim, dan organisasi ke yang terbaik. Agar efektivitas manajemen kinerja tercapai, organisasi bisnis perlu mengembangkan supervisi dalam melakukan perbaikan manajemen kinerja. Model manajemen kinerja yang terdiri dari empat tahap (perencanaan, implementasi, evaluasi, dan kompensasi) dapat dipergunakan untuk perbaikan manajemen kinerja.
\end{abstract}

Kata Kunci: Manajemen, Kinerja

\section{A. PENDAHULUAN}

Dalam pengelolaan sebuah organisasi atau perusahaan, diperlukan tata kelola atau manajerial yang baik. Pengetahuan dasar manajemen perlu dipahami dan diterapkan dengan baik oleh manajer sehingga akan sangat membantu dalam melaksanakan tugastugasnya dalam upaya mencapai tujuan organisasi. Manajemen yang baik adalah kunci kesejahteraan masyarakat yang terdiri dari berbagai macam organisasi.Salah satu aspek kunci dalam manajemen adalah bagaimana manajer dapat mengenali peran dan pentingnya para pihak yang akan menunjang pencapaian tujuan perusahaan.

Pengeluaran organisasi dalam sumber daya manusia adalah paling dominan dibanding pengeluaran dalam sumber daya yang lain. Dalam persaingan yang semakin ketat di pasar global sekarang ini, banyak organisasi bisnis terkena musibah kalang bersaing, menderita kerugian, bahkan menderita kebangkrutan, yang disebabkan rendahnya produktivitas sumber daya manusia dalam organisasi bisnis tersebut. Masalah yang menimpa organisasi bisnis tersebut dapat diselesaikan dengan mencari penyebab pokok yang menimbulkan masalah tersebut. Penyebab umum masalah tersebut adalah karena organisasi bisnis masih menerapkan manajemen kinerja (performance management) tradisional.

Dalam sistem ekonomi global yang merupakan sistem tanpa batas-batas Negara yang secara bertahap menjadi kenyataan, lingkungan bisnis cepat sekali berubah. Terutama dengan didukung oleh perkembangan teknologi informasi dan transportasi yang 
semakin pesat, globalisasi menjanjikan kesempatan setiap orang di mana saja untuk akses ke yang terbaik di seluruh dunia. Makalah ini membahas bagaimana cara melakukan perbaikan manajemen kinerja untuk mengantar kinerja karyawan, tim, dan organisasi ke yang terbaik.

Manajemen merupakan suatu proses yang sangat dibutuhkan dalam dunia perusaan, karena dalam proses manajemen terdapat langkah-langkah atau tahapan dalam mencapai tujuan perusahaan sehingga dapat mencapai tujuan tersebut secara efektif dan efisien.

Selain proses manajemen yang perlu diperhatikan dalam sebuah instansi atau organisasi, kinerja dalam sebuah instansi juga perlu diperhatikan. Karena, kinerja merupakan hasil kerja dan juga penilaian atas kerja seseorang yang berkecimpung dalam dunia kerja sebuah instansi. Oleh karenanya, kinerja juga membutuhkan manajemen, agar hasil yang diperoleh atau kinerja dari para pekerja atau karyawan dapat mencapai hasil yang ditujukan oleh perusahaan.

Melaksanakan manajemen kinerja akan memberikan manfaat bagi organisasi, tim, dan individu. Manajemen kinerja mendukung tujuan menyeluruh organisasi dengan mengaitkan pekerjaan dari setiap pekerja dan manajer pada keseluruhan unit kerjanya.

\section{B. PENGERTIAN MANAJEMEN KINERJA}

Kata Manajemen Kinerja merupakan penggabungan dari kata manajemen dan kinerja. Manajemen berasal dari kata to manage yang berarti mengatur. Menurut George $R$ Terry dalam bukunya Principles of Management, Manajemen merupakan suatu proses yang menggunakan metode ilmu dan seni untuk menerapkan fungsi-fungsi perencanaan, pengorganisasian, pengarahan dan pengendalian pada kegiatan-kegiatan dari sekelompok manusia yang dilengkapi dengan sumber daya/faktor produksi untuk mencapai tujuan yang sudah ditetapkan lebih dahulu, secara efektif dan efisien. Sedangkan menurut John $R$ Schermerhorn Jr dalam bukunya Management, manajemen adalah proses yang mencakup perencanaan, pengorganisasian, pengarahan dan pengendalian terhadap penggunaan sumber daya yang dimiliki, baik manusiadan material untuk mencapai tujuan.

Dari beberapa definisi manajemen yang diberikan oleh para ahli, dapat disimpulkan manajemen mencakup tiga aspek, yaitu:

a. Pertama : manajemen sebagai proses

b. Kedua : adanya tujuan yang telah ditetapkan

c. Ketiga : mencapai tujuan secara efektif dan efisien

Kata kinerja merupakan singkatan dari kinetika energi kerja yang padanannya dalam bahasa Inggris adalah performance, yang sering diindonesiakan menjadi kata performa. (Wirawan, 2009) 
Pengertian Kinerja menurut beberapa ahli adalah sebagai berikut: (Veithzal Rivai dan Ahmad Fawzi, 2005)

1. Kinerja merupakan seperangkat hasil yang dicapai dan merujuk pada tindakan pencapaian serta pelaksanaan sesuatu pekerjaan yang diminta (Stolovitch and Keeps, 1992)

2. Kinerja merupakan salah satu kumpulan total dari kerja yang ada pada diri pekerja (Griffin, 1987)

3. Kinerja merupakan suatu fungsi dari motivasi dan kemampuan. Untuk menyelesaikan tugas atau pekerjaan seseorang harus memiliki derajat kesediaan dan tingkat kemampuan tertentu. Kesediaan dan ketrampilan seseorang tidaklah cukup efektif untuk mengerjakan sesuatu tanpa pemahaman yang jelas tentang apa yang akan dikerjakan dan bagaimana mengerjakannya (Hersey and Blanchard, 1993)

4. Kinerja merujuk kepada tingkat keberhasilan dalam melaksanakan tugas serta kemampuan untuk mencapai tujuan yang telah ditetapkan. Kinerja dinyatakan baik dan sukses jika tujuan yang diinginkan dapat tercapai dengan baik (Donelly, Gibson and Ivancevich, 1994)

5. Kinerja sebagai kualitas dan kuantitas pencapaian tugas-tugas, baik yang dilakukan oleh individu, kelompok maupun perusahaan (Schermerhorn, Hunt and Osborn, 1991)

6. Kinerja sebagai fungsi interaksi antara kemampuan (Ability=A), motivasi (motivation=M) dan kesempatan (Opportunity=0) atau Kinerja = $f(\mathrm{~A} \times \mathrm{M} \times 0)$; artinya: kinerja merupakan fungsi dari kemampuan, motivasi dan kesempatan (Robbins,1996)

Dengan demikian, kinerja adalah kesediaan seseorang atau kelompok orang untuk melakukan sesuatu kegiatan dan menyempurnakannya sesuai dengan tanggung jawabnya dengan hasil seperti yang diharapkan.

Dari kedua kata manajemen dan kinerja, jika digabungkan menjadi satu kata baru yaitu Manajemen Kinerja (Performance Management). Beberapa definisi diungkapkan oleh para ahli sebagai berikut: (Wibowo, 2007)

1. Manejemen kinerja sebagai proses komunikasi yang dilakukan secara terus menerus dalam kemitraan antara karyawan dengan atasan langsungnya. Proses komunikasi ini meliputi kegiatan membangun harapan yang jelas serta pemahaman mengenai pekerjaan yang akan dilakukan (Bacal, 1994).

2. Manajemen kinerja sebagai sarana untuk mendapatkan hasil yang lebih baik dari organisasi, tim dan individu dengan cara memahami dan mengelola kinerja dalam suatu kerangka tujuan, standar, dan persyaratan-persyaratan atribut yang disepakati (Armstrong, 2004). 
3. Manajemen kinerja merupakan gaya manajemen yang dasarnya adalah komunikasi terbuka antara manajer dan karyawan yang menyangkut penetapan tujuan, memberikan umpan balik baik dari manajer kepada karyawan maupun sebaliknya (Schwartz, 1999)

4. Manajemen kinerja merupakan dasar dan kekuatan pendiring yang berada di belakang semua keputusan organisasi, usaha kerja dan alokasi sumberdaya (Costello, 1994)

5. Dengan memperhatikan pendapat para ahli, maka dapat dirumuskan bahwa pada dasarnya manajemen kinerja merupakan gaya manajemen dalam mengelola sumberdaya yang berorientasi pada kinerja yang melakukan proses komunikasi secara terbuka dan berkelanjutan dengan menciptakan visi bersama dan pendekatan strategis serta terpadu sebagai kekuatan pendorong untuk mencapai tujuan organisasi.

\section{MENGAPA MANAJEMEN KINERJA DIPERLUKAN}

Suatu organisasi dibentuk untuk mencapai tujuan organisasi. Pencapaian tujuan organisasi menunjukkan hasil kerja/prestasi organsisasi dan menunjukkan kinerja organisasi. Hasil kerja organisasi diperoleh dari serangkaian aktivitas yang dijalankan. Aktivitas tersebut dapat berupa pengelolaan sumberdaya organisasi maupun proses pelaksanaan kerja yang diperlukan untuk mencapai tujuan organisasi. Untuk menjamin agar aktivitas tersebut dapat mencapai hasil yang diharapkan, diperlukan upaya manajemen dalam pelaksanaan aktivitasnya.

Dengan demikian, hakikat manajemen kinerja adalah bagaimana mengelola seluruh kegiatan organisasi untuk mencapai tujuan organisasi yang telah ditetapkan sebelumnya.

Manajemen kinerja bukannya memberi manfaat kepada organisasi saja tetapi juga kepada manajer dan individu. Bagi organisasi, manfaat manajemen kinerja adalah menyesuaikan tujuan organisasi dengan tujuan tim dan individu, memperbaiki kinerja , memotivasi pekerja, meningkatkan komitmen, mendukung nilai-nilai inti, memperbaiki proses pelatihan dan pengembangan, meningkatkan dasar ketrampilan, mengusahakan perbaikan dan pengembangan berkelanjutan, mengusahakan basis perencanaan karier, membantu menahan pekerja terampil agar tidak pindah, mendukung inisiatif kualitas total dan pelayanan pelanggan, mendukung program perubahan budaya.

Bagi manajer, manfaat manajemen kinerja antara lain: mengupayakan klarifikasi kinerja dan harapan perilaku, menawarkan peluang menggunakan waktu secara berkualitas, memperbaiki kinerja tim dan individual, mengusahakan penghargaan nonfinansial pada staf, membantu karyawan yang kinerjanya rendah, digunakan untuk mengembangkan individu, mendukung kepemimpinan, proses motivasi dan 
pengembangan tim, mengusahakan kerangka kerja untuk meninjau ulang kinerja dan tingkat kompensasi.

Bagi individu, manfaat manajemen kinerja antara lain dalam bentuk: memperjelas peran dan tujuan, mendorong dan mendukung untuk tampil baik, membantu pengembangan kemampuan dan kinerja, peluang menggunakan waktu secara berkualitas, dasar objektivitas dan kejujuran untuk mengukur kinerja, dan memformulasi tujuan dan rencana perbaikan cara bekerja dikelola dan dijalankan.

Menurut Costello (1994) manajemen kinerja mendukung tujuan menyeluruh organisasi dengan mengaitkan pekerjaan dari setiap pekerja dan manajer pada misi keseluruhan dari unit kerjanya. Seberapa baik kita mengelola kinerja bawahan akan secara langsung mempengaruhi tidak saja kinerja masing-masing pekerja secara individu dan unit kerjanya, tetapi juga kinerja seluruh organisasi.

Apabila pekerja telah memahami tentang apa yang diharapkan dari mereka dan mendapat dukungan yang diperlukan untuk memberikan kontribusi pada organisasi secara efisien dan produktif, pemahaman akan tujuan, harga diri dan motivasinya akan meningkat. Dengan demikian, manajemen kinerja memerlukan kerja sama, saling pengertian dan komunikasi secara terbuka antara atasan dan bawahan.

\section{PROSES MANAJEMEN KINERJA}

1. Masukan.

Manajemen kinerja membutuhkan berbagai masukan yang harus dikelola agar dapat saling bersinergi dalam mencapai tujuan organisasi. Masukan tersebut berupa: sumberdaya manusia (SDM), modal, material, peralatan dan teknologi serta metode dan mekanisme kerja.

Manajemen Kinerja memerlukan masukan berupa tersedianya kapabilitas SDM, baik sebaga perorangan maupun tim. Kapabilitas SDM diwujudkan dalam bentuk pengetahuan, keterampilan dan kompetensi. SDM yang memiliki pengetahuan dan keterampilan diharapkan dapat meningkatkan kualitas proses kinerja maupun hasil kerja. Sedangkan kompetensi diperlukan agar SDM mempunyai kemampuan yang sesuai dengan kebutuhan organisasi sehingga dapat memberikan kinerja terbaiknya.

2. Proses.

Manajemen kinerja diawali dengan perencanaan tentang bagaimana merencanakan tujuan yang diharapkan di masa yang akan datang, dan menyusun semua sumberdaya dan kegiatan yang diperlukan untuk mencapai tujuan. Pelaksanaan rencana dimonitoring dan diukur kemajuannya dalam mencapai tujuan. Penilaian dan peninjauan kembali dilakukan untuk mengoreksi dan menentukan langkah-langkah yang diperlukan bila terdapat deviasi terhadap rencana. Manajemen kinerja menjalin terjadinya saling menghargai kepentingan diantara pihak-pihak yang terlibat dalam proses kinerja. Prosedur 
dalam manajemen kinerja dijalankan secara jujur untuk membatasi dampak meerugikan pada individu. Proses manajemen kinerja dijalankan secara transparan terutama terhadap orang yang terpengaruh oleh keputusan yang timbul dan orang mendapatkan kesempatan melalui dasar dibuatnya suatu keputusan.

\section{Keluaran.}

Keluaran merupakan hasil langsung dari kinerja organisasi, baik dalam bentuk barang maupun jasa. Hasil kerja yang dicapai organisasi harus dibandingkan dengan tujuan yang diharapkan . Keluaran dapat lebih besar atau lebih rendah dari tujuan yang telah ditetapkan. Bila terdapat deviasi akan menjadi umpan balik dalam perencanaan tujuan yang akan datang dan impelementasi kinerja yang sudah dilakukan.

4. Manfaat.

Selain memperhatikan keluaran, manajemen kinerja juga memperhatikan manfaat dari hasil kerja. Dampak hasil kerja dapat bersifat positif bagi organisasi, misalnya karena keberhasilan seseorang mewujudkan prestasinya berdampak meningkatkan motivasi sehingga semakin meningkatkan kinerja organisasi. Tetapi dampak keberhasilan sesorang dapat bersifat negatif, jika karena keberhasilannya ia menjadi sombong yang akan membuat suasana kerja menjadi tidak kondusif.

\section{E. EVALUASI}

Kegiatan dan pekerjaan apapun akan selalu diikuti dengan suatu evaluasi dengan tujuan untuk mengukur seberapa jauh tingkat keberhasilan dan kinerjanya Perusahaan, kelompok atau individu, serta hambatan dan kekurangan apa saja yang perlu penyempurnaan dikemudian hari. Disamping itu dengan metoda penilaian kinerja yang benar akan dapat terpecahkan bagaimana cara meningkatkan kompetensi karyawan.

Bagian penting dalam pengelolaan pembangunan adalah evaluasi yang mantap atas pelaksanaan rencana pembangunan. Evaluasi dilakukan untuk memperoleh umpan balik agar dapat dikenali secara dini peyimpanganpenyimpangan pelaksanaan dari rencana pembangunan, dan kemudian dapat dirumuskan langkah-langkah perbaikan yang tepat sasaran dan tepat waktu.

Evaluasi dilakukan dengan merujuk pada lintasan sebab akibat, melalui penetapan indikator kinerja.

Pada hakekatnya sistem menejenen kinerja adalah proses yang digunakan untuk mengidentifikasi, mendorong, mengukur, mengevaluasi, meningkatkan, dan memberikan penghargaan terhadap kinerja karyawan. Kegiatan proses pengamatan terhadap pelaksanaan pekerjaan oleh seorang pekerja baik pengamatan terhadap tenaga kerja itu sendiri, terhadap proses kerjanya, maupun terhadap hasil kerjanya. Dari hasil observasi itu dilakukan pengukuran yang dinyatakan dalam bentuk penetapan keputusan mengenai kebehasilan atau kegagalannya dalam bekerja. 
Perkembangan objek dari penilaian karyawan dapat dilihat dari definisi penilaian kinerja. Menurut Hariandja, penilaian kinerja adalah proses organisasi dalam menilai kinerja para karyawannya. juga sebenarnya telah menunjukkan apa yang dinilai dalam proses evaluasi kinerja tersebut, yang dimulai dalam proses evaluasi dimulai dari kemampuan (ability), personalitas (traits), perilaku (behavior), serta hasil (result).

Perilaku seseorang dalam proses pelaksanaan pekerjaan berperan penting dalam peningkatan kinerja. Oleh karena itu, "job-centered approach" disebut juga evaluasi kinerja yang berorientasi pada proses. Oleh karena penilaian kinerja atas proses ini menekankan pada perilaku karyawan dalam proses kerja tersebut, maka penilaian kinerja atas dasar "job-cenetred" disebut juga sebagai teknik "behavioral anchored rating scale". Jadi penilaian kinerja didasarkan pada baik buruknya seseorang.

Pergeseran kemudian terjadi kearah orientasi "output", yaitu penilaian kinerja seseorang didasarkan pada hasil output dan biasanya juga disebut sebagai "Result Oriented Performance Appraisal". Penilaian kinerja atas dasar result atau sasaran biasanya dilakukan dalam manajemen yang berbasis pada MBO (Manajement By Objectives).

Komponen dari performances adalah individual performer (lebih bersifat tradisional, terfokus pada personality dari seorang individu, yang menilai seorang individu berdasarkan perilakunya dan fokus pada hasil yang dicapai seseorang individu).

Evaluasi kinerja adalah suatu metode dan proses penilaian dan pelaksanaan tugas seseorang atau sekelompok orang atau unit-unit kerja dalam satu perusahaan atau organisasi sesuai dengan standar kinerja atau tujuan yang ditetapkan lebih dahulu. Evaluasi kinerja merupakan cara yang paling adil dalam memberikan imbalan atau penghargaan kepada pekerja.

Tujuan evaluasi kinerja adalah untuk menjamin pencapaian sasaran dan tujuan perusahaan dan juga untuk mengetahui posisi perusahaan dan tingkat pencapaian sasaran perusahaan, terutama untuk mengetahui bila terjadi keterlambatan atau penyimpangan supaya segera diperbaiki, sehingga sasaran atau tujuan tercapai. Hasil evaluasi kinerja individu dapat dimanfaatkan untuk banyak penggunaan.
1) Peningkatan kinerja
2) Pengembangan SDM
3) Pemberian kompensasi
4) Program peningkatan produktivitas
5) Program kepegawaian
6) Menghindari perlakuan diskriminasi 


\section{F. KOMPENSASI}

Pengertian kompensasi menurut Wibowo (2007:157) adalah kontra prestasi terhadap penggunaan tenaga atau jasa yang telah diberikan oleh tenaga kerja. Menurut Tulus dalam Jurnal Bahrur Yaman (2009) kompensasi atau balas jasa didefinisikan sebagai pemberian penghargaan langsung maupun tidak langsung, financial maupun non financial yang adil dan layak kepada karyawan atas sumbangan mereka dalam pencapaian tujuan organisasi.

Berdasarkan pendapat para ahli di atas, maka dapat disimpulkan bahwa kompensasi merupakan suatu balas jasa atas kontribusi dan prestasi yang diberikan oleh tenaga kerja kepada organisasi.

Di dalam kompensasi terdapat sistem insentif yang menghubungkan kompensasi dengan kinerja. Dengan kompensasi, pekerja diberikan penghargaan berdasarkan kinerja dan bukan berdasarkan senioritas atau jumlah jam kerja (Werther dan Davis, 1996:408).

Menurut Wibowo (2007:158) dilihat dari cara pemberiannya, kompensasi dapat dibedakan menjadi kompensasi langsung dan kompensasi tidak langsung. Kompensasi langsung merupakan kompensasi manajemen seperti upah dan gaji atau pay for performance, seperti insentif dan Gain Sharing. Sementara itu, kompensasi tidak langsung dapat berupa tunjangan atau jaminan keamanan dan kesehatan.

Pemberian kompensasi dapat terjadi tanpa ada kaitannya dengan kinerja prestasi, seperti upah dan gaji. Upah adalah kompensasi dalam bentuk uang dibayarkan atas waktu yang telah dipergunakan, sedangkan gaji adalah kompensasi dalam bentuk uang yang dibayarkan atas pelepasan tanggung jawab atas pekerjaan. Upah dipergunakan untuk memberikan kompensasi kepada tenaga kerja yang kurang terampil, sedangkan untuk tenaga terampil biasanya digunakan pengertian gaji.

Namun, kompensasi dapat pula diberikan dalam bentuk insentif, yang merupakan kontra prestasi di luar upah dan gaji, dan mempunyai hubungan dengan prestasi sehingga dinamakan pula sebagai pay for performance atau pembayaran atas prestasi.

Apabila upah dan gaji diberikan sebagai kontra prestasi atas kinerja standar pekerja, dalam insentif merupakan tambahan kompensasi atas kinerja di atas standar yang ditentukan. Adanya insentif diharapkan menjadi faktor pendorong untuk meningkatkan prestasi kerja di atas standar. Di samping upah, gaji dan insentif, kepada pekerja diberikan rangsang lain berupa penghargaan atau reward. Perbedaan antara insentif dan reward adalah, insentif sifatnya member motivasi agar pekerja lebih meningkatkan prestasinya, pada reward, pekerja lebih bersifat pasif. Atas prestasi kerjanya, atasan memberikan penghargaan tambahan lain kepada pekerja.

Bentuk kompensasi lain berupa tunjangan, yang pada umumnya tidak dikaitkan dengan prestasi kerja. Tunjangan lebih banyak dikaitkan dengan pemberian 
kesejahteraan dan penciptaan kondisi kerja sehingga pekerja menjadi lebih merasa nyaman dan merasa mendapat perhatian atasan.

\section{G. SIMPULAN}

Manajemen kinerja didefenisikan oleh Bacal (1999) sebagai proses komunikasi yang berkesinambungan yang dilakukan dalam kemitraan antara seorang karyawan dan atasan.

Jadi, kesimpulan dari manajemen kinerja adalah kegiatan yang mengkaji ulang kinerja secara berkesinambungan untuk meningkatkan dan mengembangkan kinerja lebih lanjut

\section{DAFTAR PUSTAKA}

Erinie Tisnawati , Pengantar Manajemen, Jakarta:Kencana Prenada Media Group, 2008 Iman Suhartono (2013) Jurnal Manajemen Kinerja Pada Perusahaan Bisnis Dari Manajemen Kinerja Tradisional Ke Manajemen Kinerja Baru.

Irine Diana sari wijayanti, SE., MM, Manajemen, yogyakarta: Mitra Cendikia Pres, 2008, CN Parkison, Manajemen Efektif, Semarang: Dahara Prize, 1986, Ismail Solihin, Pengantar Manajemen, Jakarta: Erlangga, 2009, Irine Diana sari wijayanti, SE., MM, Manajemen, yogyakarta: Mitra Cendikia Pres, 2008, CN Parkison, Manajemen Efektif, Semarang: Dahara Prize, 1986, Ismail Solihin, Pengantar Manajemen, Jakarta: Erlangga, 2009, https://dwiiba.wordpress.com/manajemen-kinerja/ Wibowo. 2007. Manajemen Kinerja. Jakarta : PT. Raja Grafindo Persada. 